and Mathematical Chemistry." The main problem to which the work addressed itself respected the nature and properties of the imponderable matter, ether, but its arguments were, in the main, drawn from fancy more than from experience. The work was divided into three parts. The first part, the Constitution of Bodies, formulated the theory that the ponderable atoms were not qualitatively, but only quantitatively, distinguished from one another; that the elastic effect of matter on ether, as on ponderable substances, diminished with the distance; and that the density of the ether ranged round ponderable matter did not diminish in proportion to the distance from the mass of atoms, but increased in proportion to the distance. As essential to the constitution of the bodies was further advanced the pressure of ether on the particles of ether ranged round the ponderable atoms. The second part, the Principles of Chemis try, proceeded from the hypothesis that a material particle was capable of attracting only one, or quite few, particles of ether, acting in such a manner, namely, that a fraction of the attractive force, now of the particle of ether, now of the mass particle, was kept in abeyance (conditions which, for reasons otherwise altogether unexplained, were termed "electro-negative" and "electro-positive" respectively), and made use of an accidental property of the curve of the density of elements contained in L. Meyer's "Modern Theory of Chemistry," namely, that in the case of the maxima and minima of this curve, elements related electro-negatively to the neighbouring elements in the curve always passed over to such in which the reverse condition obtained. in order, by calculations described by the author himself as highly uncertain, to determine the molecular magnitude of some elements and the number of particles of ether attracted by their atoms. The third part, the Doctrine of Heat, propounded heat as elastic concussions ; in elaborate calculations brought forward for some examples of numbers the argument that the occurrence of the stationary state was explainable under this assumption likewise; and contended against the MariotteGay-Lussac and Avogadrolaws, which were incapable of rightly explaining the facts, seeing that these laws and their deduction took no account whatever of the imponderable ether and the pressure of ether.

\section{THE HISTCRY OF FOSSIL CROCODILES 1}

$\mathrm{IN}$ this communication the author endeavoured to summarise the main facts already known regarding the palæontological history of the Crocodilia, with full references to the principal literature of the subject. After some preliminary remarks upon the structure and distribution of the living members of the order, the leading types of each geological period were successively considered ; and the paper concluded by discussing the bearing of these facts upon the evolution of the Crocodilia, as determined by Prof. Huxley in 1875 . The earliest crocodilians hitherto discovered are Belodm, Stagonolepis, and Parasuchus, from the Upper Trias--the first-named being met with on the Continent, in India, and in North America; the second, solely known from the yellow sandstones of Elgin; and the third, only recorded as yet from India. The Rhatic Beds and Lower and Middle Lias do not appear to have yielded any remains of this order, but numerous examples have been found in the Upper Lias, and some in a remarkable state of preservation. At present, however, the precise systematic relationships of the Liassic forms have not been very satisfactorily deter. mined, and those from British cleposits are especially in need of further study: there are probably two generic types, Mystriosaurus and Pelaoosaurus, and, if the latest researches are to be followed, it would seem that only two species of each are definitely known. In England, according to M. Deslongchamps, two distinct forms, Mystriosaurus chap. mani and Pelagosaurus brongniarti, have been continually described under the name of Teleosaurus chapmani. With the Lower Oolites, Teleosaurus proper makes its appearance, and ranges at least as far upwards as the Kimmeridge Clay, from which Mr. J. W. Hulke has described a characteristic snout (T. megarhinus). Steneosaurus is also a Lower Oolite form, ranging to the Oxford Clay ; its British representatives are somewhat imperfectly known, though very complete descriptions have been published of well-preserved cranial fossils from French deposits. Metriorlunnchus is another genus, from the Middle

' Abstract of a Paper read at the meeting of the Geologists' Association on December 4, 1885, by Mr. A. Smith Woodward, F.G.S., of the British Museum (Natural History). and Upper Oolites, very fully elucidated by M. Deslongchamps in France, but scarcely determined hitherto in English strata. Two forms described by Prof. Phillips under the names of Steneosaurus falpebrosus (Kimmeridgian), and Steneosaurus gra. cilis (Portlandian) are truly referable to Metriorhynchus, and fragments agreeing specifically with some of the French Metriorhynchs are also recorded. The Upper Oolites also yield the remains of Crocodilia with comparatively short and stout skulls, and very complete specimens have been discovered in the Kimmeridge Clay both of England and the Continent. They belong to the genera Dakosaurus and Mashimosazurus, the former having also been described by Sir Richard Owen under the name of Plesiosuchus. Teleosaurians occur rarely in the Wealden and Purbeck Beds -though one or two well-preserved crania of Macrorkynchus are known in Germany-and they finally dis. appear in the Upper Cretaceous series, where they are represented by the scanty remains of Hyposaurus and Enaliosuchus. Broad-faced crocodilians, adapted for a more terrestrial mode of life than the Teleosaurs, occur somewhat abundantly in the Wealden and Purbeck Beds, and are represented by Goniopholis, Nannosuchus, Ozeniasuchus, Theriosuchus, and a remarkably interesting genus-Bernissartia-recently described by M. Dollo from the now classical deposit of Bernissart in Belgium. The latter, though decidedly Mesosuchian, approaches the living crocodiles and alligators much more closely than any of its congeners, both in the characters of its dermal armour and in certain parts of the skull. The earliest evidence of procolian crocodiles hitherto made known is from the Cambridge Greensand and the nearly equivalent Gosau Beds of Vienna ; Prof. H. G. Seeley has described a few vertebræ, teeth, and fragments of limbbones, and regards these as referable to at least three specific types. The Upper Cretaceous beds of France and the United States bave yielded still more satisfactory remains-including skulls - howing that the Eusuchian sub-order dates back beyond Eocene times; and some of these fossils appear almost indistinguishable from the living genus Gavialis. The early Tertiary deposits, both of England and the Continent, are remarkable as affording traces of gavials, crocodiles, and alligators (or alligatoroid genera) associated together, while the three families share no common area of the earth's surface at the present time; the Eocene types, moreover, appear to be rather less differentiated than is the case in the existing fauna. In conclusion, it may be said that the abundant acquisitions of fossil Crocodilia during the last ten years have fully confirmed the views of Prof. Huxley, laid before the Geological Society in 1875; and the Wealden and Purbeck discoveries, particularly, have brought to light facts which were then little more than probable surmises based upon very fragmentary materials.

\section{PROFESSOR SYLVESTER'S LECTURE “ON} THE METHOD OF RECIPROCANTS AS CONTAINING AN EXHAUSTIVE THEORY OF THE SINGULARITIES OF CURVES"

PROFESSOR SYLVESTER sends us the following corrections and additions to his lecture recently given in NATURE (January 7, p. 222) :-

\section{Errata}

P. 223 , rst column, line 27 , for "requirements" read "acquirements."

P. 224, Ist column, line 37, for geometrical adjustment read numerical adjustment.

$$
\text { P. } 225 \text {, in the footnote, for } \frac{\eta^{\prime \prime \prime}}{\eta} \text { read } \frac{\eta^{\prime \prime \prime}}{\eta^{\prime}} \text {. }
$$

P. 226, 2nd column, line 9, p. 227, Ist column, lines 14,20 , $22,3 \mathrm{I}, 34,44$, and 2 nd column, line 16 from bottom, in all thees places for $\tau$ read $t$, and in the last for $\tau-\tau^{\prime}$ read $t-t^{\prime}$.

P. 226, 2nd column, line 5,

$$
\begin{aligned}
& \text { for } \frac{d y}{d x^{2}}, \frac{d y}{d x^{3}}, \frac{d y}{d x^{4}}, \ldots \\
& \text { read } \frac{d^{2} y}{d x^{2}}, \frac{d^{3} y}{d x^{3}}, \frac{d^{4} y}{d x^{4}}, \ldots
\end{aligned}
$$

P. 226 , 2nd column, line 20 , for "operation" read "operator." P. 228, Ist column, line $\mathrm{I}$, for $\tau$ read $t$.

P. 229, in the Ist line of the footnote in the Ist column, for "generating fraction" read "fractional generating function." 
P. 229, the I 7 th line of the footnote should be

$$
\frac{4 a^{2}}{2} \delta_{b}+5 a b \delta_{c}+6\left(a c+\frac{b^{2}}{2}\right) \delta_{d}+7(a d+b c) \delta_{e} .
$$

P. 229, line 2I of footnote, for $\frac{c^{2}}{2} \operatorname{read} \frac{b^{2}}{2}$.

P. 229, the 22nd line of the footnote should be

$4 a^{2} \delta_{b}+5(a b+b a) \delta_{c}+6\left(a c+b^{2}+c a\right) \delta_{d}+7(a d+b c+c b+d a) \delta_{e}+\ldots$

P. 230 , for $\pi \rho \alpha \gamma \mu \alpha \tau \omega \nu$ read $\pi \rho \alpha \gamma \mu \alpha \tau \omega \nu$.

P. 230, 2nd column, line ro from bottom, for "Buckkeim" read "Buchheim."

P. 23I. - The greater circle has been erroneously represented as cutting the ellipse. It should pass outside it, thus-

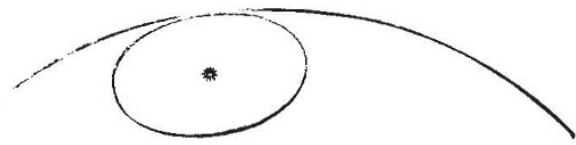

and its centre should be indicated by an asterisk, as well as that of the smaller circle.

P. 231, Chart 5, and p. 226, the syzygy should be in both places

$(n-\mathrm{I})^{2}\left(\frac{d \phi}{d y}\right)^{3} a+n(n-\mathrm{I})\left\{\frac{d^{2} \Phi}{d x^{2}} \cdot \frac{d^{2} \Phi}{d y^{2}}-\left(\frac{d^{2} \Phi}{d x d y}\right)^{2}\right\} \Phi=z^{2} H$.
P. 23I, Chart 2, in the last binariant Protomorph but one, for $+5 a b e$, read $-5 a b e$.

Chart 6, last line but one, for $H+\Lambda U$ read $H=\Lambda U$.

For "Boole-Mongian" read "Boolo-Mongian" passim.

Those desirous of obtaining systematic information on the subject of the lecture may consult the following recent articles from the pen of its author, viz. one on "Schwarzian Derivatives," followed by another on "Reciprocants" in the Mathematical Messenger, four "Sur une nouvelle théorie de formes algébriques," a fifth " Sur les Invariants Différentiels," which have already appeared, and a sixth "Sur les réciprocants purs irréductibles du quatrième ordre," about to appear in the Comptes rendus of the Institute.

It may be as well to mention that the papers in the Messenger were given in long after the dates which the numbers of the Messenger bear on their cover, those dates being by some months anterior to the time of their actual issue. In the absence of this explanation the theory would appear to have been in print long before the time when it is stated to have been discovered.

\section{UNIVERSITY AND EDUCATIONAL} INTELLIGENCE

OXFORD.-Prof. Stirling succeeds Dr. Gamgee as an examinei in the Honour School of Natural Science, not Prof. BurdonSanderson, as stated last week.

CAmbridge. - Mr. A. E. Shipley, B.A., Scholar of Christ's College, has been appointed Demonstrator of Comparative Anatomy. Mr. Shipley was placed in the first class in the Natural Sciences Tripos Part II., for Zoology and Comparative Anatomy.

It is recommended by the Council of the Senate that the University should now take over the machinery and other plant of the Engineering School belonging to Prof. Stuart. In 1883 its value was estimated at $2500 l$. It has since been considerably added to. Out of the receipts from students' fees and for pay. ments for work done for University departments and private persons, the machinery has been kept in good repair, ro per cent. has been set aside each year for depreciation, and 5 per cent. has been paid upon the capital, and in addition a profit of Iool. was made last year.

\section{SCIENTIFIC SERIALS}

The American Journal of Science, January 1886.--Observations on invisible heat-spectra and the recognition of hitherto unmeasured wave-lengths made at the Alleghany Observatory, by S. P. Langley. It is agreed that all cold bodies must not only radiate heat to still colder bodies, but, according to our present conception of radiant energy, be also capable of giving a spectrum, whether we can recognise it or not. The object of the present paper is to describe the actual formation of such spectra and the recognition of their heat in approximate terms of wave-lengths. From the author's researches it is inferred that some of the heat radiated by the soil has a probable wavelength of over 150,000 of Ângström's scale, or about twenty times the wave-length of the lowest visible line in the solar spectrum as known to Fraunhofer.-Botanical necrology of $\mathbf{1} 885$, by Asa Gray. Obituary notices are here given of Charles Wright, of Wethersfield, Connecticut (1811-1885); George W. Clinton, of Albany, New York (1807-1885); Edmond Boissier, of Geneva (1810-1885); and Johannes August Christian Roeper, of Basle (I80I-I885). - The isodynamic surfaces of the compound pendulum, by Francis E. Nipher. It is generally assumed that particles near and below the axis of suspension are retarded, and those near the bottom of the pendulum accelerated, by reason of their connection with the system, while the series of particles forming the axis of oscillation are neither accelerated nor retarded. But although this may be true as regards the time of a complete oscillation, it is shown that in any compound pendulum the particles near the bottom do not exert a constant retarding effect upon the system. - The peridotites of the "Cortlandt Series" on the Hudson River, near Peekskill, New York, by George H. Williams. In his paper the author gives a petrographical description of the most basic members of that most interesting group of massive rocks which occurs on the southern flank of the archran highlands about forty miles north of the city of New York.-Description of a meteorite from Green County, Tennessee, by Wm. P. Blake. This mass of meteoric iron, which was found by a farmer ploughing his field in 1876 , and is now in the writer's collection, weighs 290 pounds, is of the shape of a flattened cigar, 36 inches long, ro broad, and 6 thick. It clearly belongs to the class of exfoliating deliquescent irons, several examples of which have been found in Tennessee, Georgia, and North Carolina. A quantitative determination of a small slice from one end by Baumhauer's method gave iron 9I $42 \mathrm{I}$, nickel 7.955. -Tendril movements in Cusurbita maxima and C. Pepo, by D. P. Penhallow. In his paper, which is not concluded, are contained the results of a study made some years ago on the movements of the squash tendrils and terminal bud. Subsequent discoveries touching the continuity of protoplasm have served to give a clue to certain phenomena observed during the researches, but which at the time could not be satisfactorily accounted for. This clue was followed up during last summer, with the result that the true explanation of the tendril movement in Cucurbila, and possibly also in the whole family of Cucurbitacee, appears to have been reached from histolngical research.

Bulletin de l'Académie Royale de Belgique, November 1885.Solution of Wrouski's universal problem, and of another problem relating to the integration of differential equations, by $\mathrm{Ch}$. Lagrange. This is the fifth memoir devoted by the author to the elucidation and correction of Wrouski's writings. Here he demonstrates and generalises for any number of variables, the following theorem: Given a differential equation of any order $n$ :

$$
\phi\left(\frac{d^{n} x}{a t^{n}}, \frac{d^{n-1} x}{d t^{n-1}}, . . \frac{d x}{d i t}, x, t, a\right)=0,
$$

between the dependent variable $x$ and the independent variable $t$ ( $a$ being a parameter), an equation which may be integrated for $a=0$, the coefficients of the development of $x$ according to the powers of $a$ are absolutely known functions of $t$ given by simple quadratures.-Researches on the spawning of the toad (Bufo vulgaris), and on the protecting layers of the egg in the batrachian family generally, by M. Héron-Royer.-Note on the origin of diastase and on the reduction of the nitrates to nitrites, by $\mathbf{M}$. Ed. Jorissen. The author's experiments tend to confirm the views of Traube and Pfeffer, who regard the physiological character of the Bacteria and of the Mycetæe in general as profoundly different from that both of plants and animals. $\mathrm{He}$ further endeavours to show that the reduction of nitrates to nitrites by germinating grains must be attributed to the presence of the Bacteria of putrefaction in the surrounding fluid.-Experimental researches on the infuence of magnetism on polarisation in the dielectrics, by Edmond van Aubel. The object of these researches is to ascertain whether it be possible to establish a parallelism between the electro-magnetic rotation of the plane of polarisation of light, the phenomena of the reflection of light on a magnet, and Hall's discovery. But the result so far has been unsatisfactory. - Note on the late Gen. Baeyer's views regarding an annual oscillation in the level of the Baltic Sea, by Gen. Liagre. Even admitting the accuracy of the observations 